\title{
APLIKASI LAMA PERENDAMAN BENIH DENGAN MOL (Mikroorganisme lokal) DARI AKAR PUTRI MALU DALAM MEMACU PERTUMBUHAN BIBIT PADI PANDANWANGI
}

\author{
Oleh : \\ Tuti Agustina* \\ Melissa Syamsiah** \\ e-mail :melissa@unsur.ac.id
}

\begin{abstract}
ABSTRAK
Kemampuan MOL (Mikroorganisme lokal) akar putri malu dalam memacu pertumbuhan tanaman dapat dijadikan alternatif untuk meningkatkan produktivitas tanaman padi Pandanwangi pada fase vegetatif. Penelitian ini bertujuan untuk mengetahui pengaruh perlakuan lama perendaman benih dengan MOL dari akar putri malu terhadap pertumbuhan bibit tanaman padi Pandanwangi. Penelitian ini dilakukan di lahan Masyarakat Pelestari Padi Pandanwangi Cianjur (MP3C) pada bulan Januari - Maret 2018, menggunakan rancangan acak lengkap dengan 8 perlakuan termasuk Kontrol dan 3 ulangan. Perlakuan tersebut yaitu : perendaman benih dengan MOL dari akar putri malu dengan lama waktu perendaman 4 jam, 8 jam, 12 jam, 16 jam, 20 jam, 24 jam, 28 jam dan kontrol (tanpa MOL). Hasil penelitian menunjukkan bahwa secara umum perlakuan perendaman benih dengan MOL akar putri malu berpengaruh signifikan terhadap pertumbuhan bibit padi pandanwangi. Perlakuan A4 (lama perendaman benih dengan MOL selama 16 jam) menunjukkan perlakuan yang memberikan pengaruh paling baik di setiap parameter, yaitu terhadap parameter persentase perkecambahan benih, persentase bibit tumbuh normal, rata-rata tinggi tanaman, rata-rata jumlah daun, ratarata panjang akar, rata-rata bobot segar bibit padi pandanwangi .
\end{abstract}

Kata kunci : Lama perendaman, pertumbuhan bibit, MOL (Mikroorganisme lokal), padi Pandanwangi

\begin{abstract}
The ability of MOL (Local Mikroorganism) extracted from mimosa's root in spur the growth of plants is can be used as an alternative way to increase the productivity of pandanwangi rice plants in the vegetative phase. This research aimed at the assesment of the influence of long soaking pandanwangi rice seeds treatment with MOL solution of the mimosa's roots. This research was applied in the farmer society named as Masyarakat Pelestari Padi Pandanwangi Cianjur (MP3C) on January to March 2018. The treatment was adminitered using a complete randomize design with 8 treatment and 3 replications. Each unit of experiment is consisting of 100 seeds. The treatments are as followa : long soaking seeds treatment by MOL during 4 hour, 8 bour, 12 hour, 16 hour, 20 bour, 24 hour, 28 hour and control (without MOL). The results indicated that in general, treatment of seeds by soaking with MOLsolution of mimosa's roots has significant growth during seedling period and the A4 treatment (seeds soaking with MOL solution for 16 hours) gave the best result in the percentage of seed germination, as well as average of plant height, number of leaves, and biomass of seedlings.
\end{abstract}

Keywords: Long soaking, Seedling growth, MOL (Local Microorganism), Pandanwangi rice.

*) Alumni Fakultas Sains Terapan UNSUR

**) Dosen Fakultas Sains Terapan UNSUR

Aplikasi Lama Perendaman Benih dengan Mol

TUTI AGUSTINA dON MELISSA SYAMSIAH (Mikroorganisme Lokal) dari Akar Putri Malu dalam

Memacu Pertumbuhan Bibit Padi Pandanwangi

[DOCUMENT TITLE] 


\section{PENDAHULUAN}

\section{Latar Belakang}

Padi (Oryza sativa L ) merupakan bahan pangan sumber karbohidrat utama di Indonesia. Beras merupakan bahan pangan pokok bagi $95 \%$ penduduk Indonesia. Salah satu jenis padi yang sudah ditetapkan oleh Negara melalui Departemen Pertanian yaitu padi Pandanwangi. Padi varietas unggul Pandanwangi ini juga dijadikan komoditas unggul utama hasil pertanian pemerintah Kabupaten Cianjur.

Deskripsi padi Pandanwangi menurut SK Menteri Pertanian Nomor: 163/Kpts/LB240/2004 Tanggal 17 Maret 2004 adalah sebagai berikut:

Tinggi tanaman : $168 \mathrm{~cm}$

Bentuk tanaman : Kompak

Umur tanaman : 155 hari

Anak produktif : 15-18 batang

Warna helai daun : Tidak berwarna

Muka daun : Hijau

Bentuk gabah : Bulat

Warna gabah : Kuning mas

Tekstur nasi : Pulen

Bobot 1000 butir: 29,7 gram

Kadar amilosa : $24,6 \%$

Potensi hasil : :7,4ton GKG/Ha

Rata-rata hasi : $: 5,7$ ton $\mathrm{GKG} / \mathrm{Ha}$

Mengingat jenis padi Pandanwangi ini berbeda dengan jenis padi lainnya, dalam hal ini memiliki keunggulan spesifik maka harganya pun berbeda dengan jenis padi lainnya. Masyarakat kelas menengah ke atas yang memiliki tingkat pendapatan yang lebih bersedia mengeluarkan dana yang lebih besar untuk membeli beras jenis pandanwangi ini. Seiring dengan bertambahnya jumlah penduduk yang terus bertambah sehingga permintaan akan beras jenis Pandanwangi meningkat, namun proses budidaya Pandanwangi ini lumayan cukup lama sekitar 5-6 bulan berbeda dengan jenis padi lainnya membuat tidak dapat memenuhi jumlah permintaan. Oleh karena itu petani harus lebih meningkatkan produksinya dengan cepat, salah satu alternatif pemecahan masalah ini yaitu melalui penambahan bahan alami yang kegunaannya untuk mempercepat proses pertumbuhaan. Bahan alami yang dapat digunakan untuk mempercepat proses pertumbuhan salah satunya adalah MOL (Mikroorganisme lokal).

MOL yang mengandung unsur hara mikro dan makro dan juga mengandung bakteri yang berpotensi sebagai perombak bahan organik, perangsang pertumbuhan, dan sebagai agens pengendali hama dan penyakit tanaman, sehingga MOL dapat digunakan baik sebagai pendekomposer, pupuk hayati, dan sebagai pestisida organik terutama sebagai fungisida (Purwasasmita, 2009). MOL ini dapat dibuat dengan memanfaatkan bahanbahan yang ada di sekitar, seperti buahbuahan busuk, limbah sayuran, keong mas dan lain-lain.

Tanaman putri malu tumbuh liar di pinggir jalan, lapangan terlantar, dan tempat - tempat terbuka yang terkena sinar matahari. Mikroba yang ada di daerah perakaran putri malu yakni: Rhizobium (Harahap, 2008).

Berdasarkan pemaparan latar belakang di atas, maka dapat dirumuskan masalah yaitu bagaimana pengaruh perlakuan lama perendaman benih dengan MOL (Mikroorganisme lokal) dari akar putri malu dalam meningkatkan pertumbuhan bibit tanaman (fase vegetatif awal) padi Pandanwangi ?

\section{Tujuan}

Penelitian ini bertujuan untuk mengetahui pengaruh perlakuan lama perendaman benih dengan MOL (Mikroorganisme lokal) dari akar putri malu terhadap pertumbuhan bibit tanaman padi Pandanwangi. Parameter pertumbuhan yang diamati yaitu persentase benih yang berkecambah, persentase bibit tumbuh normal, tinggi tanaman, jumlah daun tanaman, bobot segar tanaman dan panjang akar tanaman. 


\section{METODE PENELITIAN}

\section{Waktu dan Tempat \\ Penelitian ini dilaksanakan di lahan Masyarakat Pelestari Padi Pandanwangi Cianjur (MP3C) KP Sayang, Kelurahan Bojongherang, Kecamatan Cianjur. Waktu pelaksanaannya dimulai pada bulan Januari 2018 sampai dengan bulan Maret 2018.}

\section{Alat dan Bahan}

Alat yang digunakan dalam penelitian ini adalah Penggaris, meteran, ember, timbangan, baskom, cangkul, pisau, saringan, talenan, baki penyemai, karung berukuran kecil, papan nama, penggaris, meteran, alat tulis, kamera.

Bahan yang digunakan dalam penelitian ini adalah benih padi Pandanwangi, MOL (Mikroorganisme lokal) dari akar putri malu, terasi, media tanam (tanah sawah), air, gula pasir, dedak, injet (air kapur), penyedap rasa.

\section{Pelaksanaan penelitian}

a. Mempersiapkan alat dan bahan yang akan digunakan

b. Membuat MOL (Mikroorganisme lokal) dari akar tanaman putri malu.

c. Pelaksanaan penelitian terdiri dari beberapa tahapan kegiatan sebagai berikut :

1. Persiapan media tanam

2. Penyemaian

3. Menghitung jumlah benih yang berkecambah dihitung pada saat sebelum tanam.

4. Pengujian pertumbuhan bibit padi Pandanwangi dilakukan dengan cara menghitung persentase bibit yang tumbuh normal dan serempak setelah 30 hst.

5. Mengukur beberapa parameter, diantaranya : tinggi tanaman, jumlah daun tanaman, panjang akar tanaman, bobot segar tanaman.

\section{Rancangan Percobaaan}

Rancangan percobaan yang digunakan pada penelitian ini adalah Rancangan Acak Lengkap (RAL) yang terdiri dari 8 perlakuan termasuk kontrol. Setiap perlakuan terdiri dari 3 ulangan. Perlakuan tersebut yaitu :

Perendaman benih dengan MOL (Mikroorganisme lokal) dari akar putri malu dengan lama waktu perendaman:
$\mathrm{A} 1=4$ jam.
$\mathrm{A} 2=8 \mathrm{jam}$
$\mathrm{A} 3=12 \mathrm{jam}$.
$\mathrm{A} 4=16 \mathrm{jam}$.
$\mathrm{A} 5=20 \mathrm{jam}$.
$\mathrm{A} 6=24 \mathrm{jam}$.
$\mathrm{A} 7=28 \mathrm{jam}$.
A8 $=$ Tanpa MOL (kontrol).

\section{Teknik Pengumpulan Data}

a. Mengitung persentase benih yang berkecambah pada saat sebelum tanam dengan rumus :

$\%$ Benih yang Berkecambah $=$

$\frac{\sum \text { Benih yang berkecambah }}{\sum \text { benih yang direndam }} \times 100 \%$

b. Menghitung persentase pertumbuhan bibit pada saat sesudah disemai dengan rumus :

Pertumbuhan Bibit $=\frac{\sum \text { Bibit yang tumbuh normal }}{\sum \text { Bibit yang Ditanam }} \times 100 \%$

Selanjutnya mengukur parameter berikut ini pada umur 30 hst, diantaranya :

- Tinggi Tanaman (TT) dengan menggunakan meteran sebagai alat ukur. Pengukuran dilakukan mulai dari pangkal batang sampai ujung daun tanaman tertinggi.

- Jumlah Daun Tanaman (JD) dihitung secara manual keseluruhan daun yang tumbuh pada setiap unit penelitian.

- Panjang Akar Tanaman (PA) dengan menggunakan meteran sebagai alat ukur, yaitu mulai dari akar yang menempel pada pangkal batang hingga ujung akar terpanjang dijumlahkan dengan panjang cabang-cabang akar.

- Berat Basah Tanaman (BB) dengan menggunakan timbangan analitik dua digit dibelakang koma. 


\section{Teknik Analisis Data}

Data diperoleh dari hasil pengamatan penelitian dianalisa menggunakan komputer dengan bantuan software MS. Exel dan Minitab ver. 16. Data yang diperoleh dianalisa, untuk mendapatkan sidik ragam percobaan digunakan tabel ANOVA atau sidik ragam, dengan uji beda nyata perlakuan menggunakan Uji Tukeys pada taraf 5\%.

\section{HASIL DAN PEMBAHASAN \\ Perkecambahan Benih}

Hasil penelitian melalui analisis table sidik ragam percobaan pengujian perlakuan lama perendaman benih padi Pandanwangi dengan MOL (Mikroorganisme lokal) akar putri malu terhadap perkecambahan benih padi Pandanwangi, menunjukkan ada pengaruh, pada taraf $\alpha 5 \%$ dengan nilai $\mathrm{P}$ value lebih kecil dari 0.05. Dengan demikian hipotesa penelitian H1 (lama perendaman benih padi Pandawangi dengan MOL (Mikroorganisme lokal) dari akar putri malu berpengaruh terhadap perkecambahan benih padi Pandanwangi) diterima.

Tabel 1. adalah rata-rata dari respon pengujian perlakuan lama perendaman benih padi Pandanwangi dengan MOL (Mikroorganisme lokal) dari akar putri malu terhadap perkecambahan benih padi pandanwangi.

Hasil pengamatan pengujian perlakuan lama perendaman benih padi pandanwangi dengan MOL (Mikroorganisme lokal) akar putri malu terhadap rata-rata jumlah benih yang berkecambah padi Pandanwangi menunjukkan respon rata-rata jumlah benih yang berkecambah yang paling tinggi (Tabel 1) yaitu perlakuan A1 (perendaman benih dengan MOL (Mikroorganisme lokal) dari akar putri malu dengan lama waktu perendaman 4 jam) $98.66 \%$, A2 (perendaman benih dengan MOL (Mikroorganisme lokal) dari akar putri malu dengan lama waktu perendaman 8 jam) $98.66 \%$ dan A4 (perendaman benih dengan MOL (Mikroorganisme lokal) dari akar putri malu dengan lama waktu perendaman 16 jam) $98.66 \%$. Nilai ratarata jumlah benih yang berkecambah ini tidak berbeda nyata dengan perlakuan A3 (perendaman benih dengan MOL (Mikroorganisme lokal) dari akar putri malu dengan lama waktu perendaman 12 jam) $97.00 \%$, A5 (perendaman benih dengan MOL (Mikroorganisme lokal) dari akar putri malu dengan lama waktu perendaman 20 jam) $98.33 \%$, A6 (perendaman benih dengan MOL (Mikroorganisme lokal)dari akar putri malu dengan lama waktu perendaman 24 jam) $98.00 \%$, dan A7 (perendaman benih dengan MOL (Mikroorganisme lokal) dari akar putri malu dengan lama waktu perendaman 28 jam) $98.00 \%$. Akan tetapi nilai rata-rata jumlah benih yang berkecambah paling tinggi tersebut berbeda nyata dengan perlakuan A8 (kontrol tanpa MOL (Mikroorganisme lokal) $65.00 \%$.

Perlakuan A1 (perendaman benih dengan MOL (Mikroorganisme lokal)dari akar putri malu dengan lama waktu perendaman 4 jam) A2 (perendaman benih dengan MOL (Mikroorganisme lokal) dari akar putri malu dengan lama waktu perendaman 8 jam) dan A4 (perendaman benih dengan MOL (Mikroorganisme lokal) dari akar putri malu dengan lama waktu perendaman 16 jam) merupakan perlakuan yang memberikan hasil yang paling tinggi pada persentase benih padi Pandanwangi yang berkecambah. Perlakuan tersebut secara statistika tidak berbeda nyata dengan perlakuan-perlakuan selain kontrol perlakuan A8 (tanpa MOL (Mikroorganisme lokal)). Kondisi ini diduga karena adanya bakteri-bakteri yang menguntungkan yang ada dalam MOL (Mikroorganisme lokal) sehingga membantu merangsang pembentukan ZPT (Zat Pengatur Tumbuh) dan mempercepat penyerapan unsur hara oleh tanaman. 
Tabel 1. Rata-rata jumlah benih padi Pandanwangi yang berkecambah pada setiap perlakuan.

\begin{tabular}{|c|c|}
\hline Perlakuan & $\begin{array}{c}\text { Rata-rata perkecambahan benih } \\
(\%)\end{array}$ \\
\hline $\begin{array}{l}\text { A1 = lama perendaman benih dengan MOL (Mikroorganisme lokal) akar } \\
\text { putri malu } 4 \text { jam }\end{array}$ & $98.66 \mathrm{a}$ \\
\hline $\begin{array}{c}\text { A2 }=\text { lama perendaman benih dengan MOL (Mikroorganisme lokal) akar } \\
\text { putri malu } 8 \text { jam }\end{array}$ & $98.66 \mathrm{a}$ \\
\hline $\begin{array}{c}\text { A3 }=\text { lama perendaman benih dengan MOL (Mikroorganisme lokal) akar } \\
\text { putri malu } 12 \mathrm{jam}\end{array}$ & $97.00 \mathrm{a}$ \\
\hline $\begin{array}{c}\text { A4 }=\text { lama perendaman benih dengan MOL (Mikroorganisme lokal) akar } \\
\text { putri malu } 16 \text { jam }\end{array}$ & $98.66 \mathrm{a}$ \\
\hline $\begin{array}{c}\text { A5 }=\text { lama perendaman benih dengan MOL (Mikroorganisme lokal) akar } \\
\text { putri malu } 20 \text { jam }\end{array}$ & $98.33 \mathrm{a}$ \\
\hline $\begin{array}{c}\text { A6 = lama perendaman benih dengan MOL (Mikroorganisme lokal) akar } \\
\text { putri malu } 24 \mathrm{jam}\end{array}$ & $98.00 \mathrm{a}$ \\
\hline $\begin{array}{c}\text { A7 }=\text { lama perendaman benih dengan MOL (Mikroorganisme lokal) akar } \\
\text { putri malu } 28 \mathrm{jam}\end{array}$ & $98.00 \mathrm{a}$ \\
\hline A8 $=$ Kontrol & $65.00 \mathrm{~b}$ \\
\hline
\end{tabular}

Sumber : Data Primer (olahan) tahun 2018

Keterangan: Angka yang diikuti dengan huruf yang sama pada kolom yang sama tidak berbeda nyata pada taraf kepercayaan 5\% dengan Uji Tukey.

MOL yang mengandung unsur hara mikro dan makro dan juga mengandung bakteri yang berpotensi sebagai perombak bahan organik, perangsang pertumbuhan, dan sebagai agens pengendali hama dan penyakit tanaman, sehingga MOL dapat digunakan baik sebagai pendekomposer, pupuk hayati, dan sebagai pestisida organik terutama sebagai fungisida (Purwasasmita, 2009). MOL ini dapat dibuat dengan memanfaatkan bahanbahan yang ada di sekitar, seperti buahbuahan busuk, limbah sayuran, keong mas dan lain-lain.

Tanaman putri malu tumbuh liar di pinggir jalan, lapangan terlantar, dan tempat - tempat terbuka yang terkena sinar matahari. Mikroba yang ada di daerah perakaran putri malu yakni: Rbizobium (Harahap, 2008).

Menurut Winarno (2011) dalam Ismail (2012), menyatakan bahwa fase akhir dari dormansi adalah fase berkecambah. Permulaan fase perkecambahan ini ditandai dengan penghisapan air (imbibisi) kemudian terjadi pelunakan kulit benih sehingga terjadi hidratasi protoplasma. Setelah fase istirahat berakhir, maka aktivitas enzimatik mulai berlangsung. Di dalam aktivitas metabolisme, giberellin yang dihasilkan oleh embrio ditranslokasikan ke lapisan aleuron sehingga menghasilkan enzim amilase. Proses selanjutnya yaitu enzim tersebut masuk ke dalam cadangan makanan dan mengkatalis proses perubahan cadangan makanan yang berupa pati menjadi gula sehingga dapat menghasilkan energi yang berguna untuk aktivitas sel dan pertumbuhan. selanjutnya Suyatmi, dkk (2006) menambahkan, perendaman benih dengan hormon pada waktu tertentu dapat menyebabkan meningkatnya proses masuknya air kedalam kulit benih, sehingga menyebabkan daya kecambah benih menjadi meningkat.

Sesuai dengan pendapat Goldsworthy dan Fisher (1992) dalam Ratnasari (2010) menyatakan bahwa, imbibisi air segera diikuti oleh kenaikan aktivitas enzim dan respirasi yang besar. Aktivitas enzim meningkatkan katabolisme, yaitu perombakan pati, lemak dan protein menjadi zat-zat yang lebih mobil yaitu gula, asam lemak dan asam amino yang dapat ditranslokasikan ke bagian pertumbuhan aktif. Proses katabolismedan translokasi yang lancar ini kemudian meningkatkan 
pertumbuhan/perkecambahan tanaman. Santoso, dkk (2014) menambahkan, perendaman benih dengan ZPT merupakan salah satu metode invigorasi untuk mempercepat tumbuhnya kecambah dan menghasilkan bibit yang vigor.

Persentase benih yang berkecambah hasilnya tidak beda nyata mulai dari perlakuan A1, A2, A3, A4, A5 , A6 dan A7 (yang diberi perlakuan dengan MOL (Mikroorganisme lokal) hal ini diduga karena ada pengaruh perendaman dengan MOL (Mikroorganisme lokal) akar putri malu terhadap jumlah benih yang berkecambah, akan tetapi waktu lama perendaman benih tidak berpengaruh terhadap jumlah benih yang berkecambah. Hal ini sesuai dengan pernyataan Kuswanto (1996) yang menyatakan bahwa proses perkecambahan benih dapat dirangsang dengan penambahan atau perlakuan dengan zat tertentu sebelum benih dikecambahkan atau pada saat proses perkecambahan sedang berlangsung. Rangsangan yang diberikan dapat meningkatkan laju imbibisi, respirasi dan metabolisme pada proses perkecambahan.

Menurut Ashari (1995) dalam Silvia (2014) bahwa bila cadangan makanan tersedia dalam jumlah sedikit maka pertumbuhan tanaman akan lemah. Disamping itu, semakin lama biji direndam juga tidak lagi menaikan kemampuan perkecambahan benih. Biji yang terlalu lama direndam akan mengakibatkan kurangnya $\mathrm{O}_{2}$ yang menyebabkan biji tersebut sulit untuk berkecambah. Hal ini di dukung dengan pendapat Sutopo (1993) dalam Silvia (2014) bahwa umumnya proses

Aplikasi Lama Perendaman Benih dengan Mol (Mikroorganisme Lokal) dari Akar Putri Malu dalam Memacu Pertumbuhan Bibit Padi Pandanwangi

[DOCUMENT TITLE] perkecambahan dapat terhambat bila penggunaan oksigen terhambat.

Pemberian air melalui perendaman merupakan salah satu upaya yang dapat dilakukan untuk mempercepat munculnya kecambah, namun perendaman yang berlebihan akan berpengaruh kurang baik yakni dapat menyebabkan biji rusak dan busuk (Angadi \& Entz, 2002; Bachmann et al., 2002; Oberbauer et al., 2005).

\section{Persentase Bibit Tumbuh Normal}

Fase pertumbuhan padi meliputi pembibitan (14 hari), vegetatif awal (0-6 mst) dan vegetatif akhir (7-11 mst). Fase generative meliputi masa reproduksi (12$16 \mathrm{mst}$ ) dan pematangan bulir (17 mstpanen) (Muhammad, 2015 dalam Rahma, 2017). Uji pertumbuhan bibit padi Pandanwangi dilakukan dengan cara menghitung persentase bibit tumbuh normal dan serempak setelah 30 hst (fase vegetatif awal) dengan hasil uji ANOVA perlakuan lama perendaman benih padi Pandanwangi dengan MOL (Mikroorganisme lokal) akar putri malu terhadap Persentase bibit tumbuh normal padi Pandanwangi, menunjukkan ada pengaruh pada taraf $\alpha \quad 5 \%$ dengan nilai $\mathrm{P}$ value lebih kecil dari 0.05. Dengan demikian H1 (lama perendaman benih padi Pandawangi dengan MOL (Mikroorganisme lokal) dari akar putri malu berpengaruh terhadap Persentase bibit tumbuh normal padi Pandanwangi) diterima.

Berikut ini adalah rata-rata dari respon pengujian perlakuan lama perendaman benih padi Pandanwangi dengan MOL (Mikroorganisme lokal)dari akar putri malu terhadap Persentase bibit tumbuh normal padi Pandanwangi. 
Tabel 2. Rata-rata Persentase bibit tumbuh normal padi Pandanwangi yang tumbuh pada setiap perlakuan (30 hst).

\begin{tabular}{|c|c|}
\hline Perlakuan & $\begin{array}{c}\text { Rata-rata pertumbuhan } \\
\text { bibit }(\%) \\
\end{array}$ \\
\hline $\begin{array}{l}\text { A1 = lama perendaman benih dengan MOL (Mikroorganisme lokal) akar } \\
\text { putri malu } 4 \text { jam }\end{array}$ & $86.66 \mathrm{a}$ \\
\hline $\begin{array}{c}\text { A2 = lama perendaman benih dengan MOL (Mikroorganisme lokal) akar } \\
\text { putri malu } 8 \text { jam }\end{array}$ & $71.66 \mathrm{ab}$ \\
\hline $\begin{array}{c}\text { A3 = lama perendaman benih dengan MOL (Mikroorganisme lokal) akar } \\
\text { putri malu } 12 \mathrm{jam}\end{array}$ & $83.33 \mathrm{a}$ \\
\hline 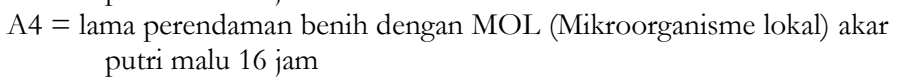 & $86.00 \mathrm{a}$ \\
\hline $\begin{array}{c}\text { A5 = lama perendaman benih dengan MOL (Mikroorganisme lokal) akar } \\
\text { putri malu } 20 \text { jam }\end{array}$ & $85.00 \mathrm{a}$ \\
\hline $\begin{array}{c}\text { A6 = lama perendaman benih dengan MOL (Mikroorganisme lokal) akar } \\
\text { putri malu } 24 \mathrm{jam}\end{array}$ & $80.66 \mathrm{a}$ \\
\hline $\begin{array}{c}\text { A7 }=\text { lama perendaman benih dengan MOL (Mikroorganisme lokal) akar } \\
\text { putri malu } 28 \text { jam }\end{array}$ & $84.66 \mathrm{a}$ \\
\hline A $8=$ Kontrol & $56.66 \mathrm{~b}$ \\
\hline
\end{tabular}

Sumber : Data Primer (olahan) tahun 2018

Keterangan: Angka yang diikuti dengan huruf yang sama pada kolom yang sama tidak berbeda nyata pada taraf kepercayaan 5\% dengan Uji Tukey.

Hasil pengamatan terhadap ratarata respon pengujian perlakuan lama perendaman benih padi pandanwangi dengan MOL (Mikroorganisme lokal) akar putri malu terhadap persentase bibit normal padi Pandanwangi menunjukkan respon paling tinggi pada perlakuan A1 (perendaman benih dengan MOL (Mikroorganisme lokal) dari akar putri malu dengan lama waktu perendaman 4 jam) $86.66 \%$, nilai ini tidak berbeda nyata dengan perlakuan A2 (perendaman benih dengan MOL (Mikroorganisme lokal) dari akar putri malu dengan lama waktu perendaman $8 \mathrm{jam}) \quad 71.66 \%, \quad \mathrm{~A} 3$ (perendaman benih dengan MOL (Mikroorganisme lokal) dari akar putri malu dengan lama waktu perendaman 12 jam) $83.33 \%$, A4 (perendaman benih dengan MOL (Mikroorganisme lokal) dari akar putri malu dengan lama waktu perendaman 16 jam) $86.00 \%, \quad$ A5 (perendaman benih dengan MOL (Mikroorganisme lokal) dari akar putri malu dengan lama waktu perendaman 20 jam) $85.00 \%$, A6 (perendaman benih dengan MOL (Mikroorganisme lokal) dari akar putri malu dengan lama waktu

Aplikasi Lama Perendaman Benih dengan Mol (Mikroorganisme Lokal) dari Akar Putri Malu dalam Memacu Pertumbuhan Bibit Padi Pandanwangi

[DOCUMENT TITLE] perendaman 24 jam) 80.66\% dan A7 (perendaman benih dengan MOL (Mikroorganisme lokal) dari akar putri malu dengan lama waktu perendaman 28 jam) $84.66 \%$. Akan tetapi berbeda nyata dengan A8 (kontrol tanpa MOL (Mikroorganisme lokal)) dengan nilai ratarata persentase jumlah bibit tumbuh normal $56.66 \%$

Perlakuan A1 (perendaman benih dengan MOL (Mikroorganisme lokal) dari akar putri malu dengan lama waktu perendaman 4 jam) merupakan perlakuan yang memberikan hasil yang paling tinggi pada jumlah bibit padi Pandanwangi yang tumbuh normal. Kondisi ini diduga karena kebutuhan tanaman akan unsur $\mathrm{N}$ (unsur hara untuk meningkatkan pertumbuhan tanaman) terpenuhi. Hal ini sesuai dengan pernyataan yang dikemukakan Thompson dan Kelly (1997) dalam Tubagus (2014) bahwa nitrogen dapat mempercepat pertumbuhan dan memberikan hasil yang lebih besar mendorong pertumbuhan vegetasi seperti daun, batang dan akar yang mempunyai peranan penting didalam tanaman. Selain dari itu, peranan unsur $\mathrm{N}$ bagi tanaman yaitu meningkatkan pertumbuhan 
tanaman menjadi hijau karena mengandung klorofil yang berperan dalam fotosintesis. Unsur tersebut juga bermanfaat untuk mempercepat pertumbuhan tinggi tanaman, memperbanyak jumlah anakan, mempengaruhi lebar dan panjang daun, membuat buah menjadi besar, menambahkan kadar protein dan lemak bagi tanaman (Pitojo, 1997 dalam Tabagus, 2014).

Hasil dari perlakuan A2 (perendaman benih dengan MOL (Mikroorganisme lokal) akar putri malu selama 8 jam) menunjukkan terjadinya persentase bibit tumbuh normal yang paling rendah dibandingkan dengan perlakuan lama perendaman benih dengan MOL (Mikroorganisme lokal)akar putri yang lainnya. Hal ini diduga karena adanya pengaruh beberapa faktor yaitu faktor luar dan faktor dalam. Risa (2007) menyatakan bahwa faktor lingkungan tersebut antara lain: nutrien, suhu, cahaya, kelembapan, PH tanah dan udara. Perkecambahan ditentukan oleh kualitas benih (vigor dan kemampuan berkecambah), perlakuan awal (pematahan dormansi), dan kondisi perkecambahan seperti suhu, air, media, cahaya, dan bebas dari OPT. Cahaya, suhu dan kelembaban merupakan tiga faktor utama yang mempengaruhi perkecambahan selama pertumbuhan bibit, kondisi media pertumbuhan seperti $\mathrm{pH}$, salinitas dan drainase menjadi penting (Bewl ey \& Bl ack, 1985 dalam Sulistyani $\mathrm{dkk}, 2014)$.

Hasil dari perlakuan A8 (tanpa
perendaman (Mikroorganisme lokal) akar putri malu) menunjukkan terjadinya persentase bibit tumbuh normal yang paling rendah. Kondisi ini dikarenakan tidak tersediannya unsur hara salah satunya unsur hara N, P dan $K$ yang cukup untuk diserap oleh tanaman sehingga pertumbuhannya tidak maksimal. Suatu tanaman apabila kekurangan unsur hara akan mengalami gangguan pertumbuhan. Seperti yang dikemukakan Manschner (1986) dalam Diana (2016) bahwa tanaman yang kahat hara $\mathrm{N}$ (nitrogen) mengakibatkan pertumbuhan yang lambat, daun pucat dan tidak hijau berseri warnanya. Tanaman yang kahat unsur P (fosfor) warna daun berubah lebih tua tetapi tidak merata sedangkan akar tumbuh tidak sempurna dan apabila kahat hara K (kalium) daun paling bawah berubah warna menjadi coklat dengan bercakbercak gelap, dalam keadaan parah daun menjadi keriting (Wijayani, dkk, 1998 dalam, Diana 2016).

\section{Tinggi Tanaman}

Parameter pertumbuhan bibit padi Pandanwangi yang diukur pertama yaitu tinggi tanaman bibit padi Pandanwangi. Perhitungan tinggi tanaman dilakukan setelah tanaman padi Pandanwangi berumur 1 MST (Minggu Setelah Tanam) sampai 4 MST (Minggu Setelah Tanam). Tinggi tanaman merupakan ukuran tanaman yang diamati sebagai indikator pertumbuhan maupun sebagai parameter untuk mengukur pengaruh lingkungan atau perlakuan yang diterapkan karena tinggi tanaman merupakan ukuran pertumbuhan yang paling mudah dilihat (Sitompul dan Guritno, 1995 dalam Rahma,2017).

Dari hasil ANOVA pengujian perlakuan lama perendaman benih padi Pandanwangi dengan MOL (Mikroorganisme lokal) akar putri malu terhadap tinggi bibit padi Pandanwangi, menunjukkan ada pengaruh pada jumlah daun tanaman padi Pandanwangi pada taraf $\alpha \quad 5 \%$ dengan nilai $\mathrm{P}$ value lebih kecil dari 0.05. Dengan demikian hipotesa perlakuan lama perendaman benih padi Pandanwangi dengan MOL (Mikroorganisme lokal) akar putri malu H0 (lama perendaman benih padi Pandawangi dengan MOL (Mikroorganisme lokal) dari akar putri malu tidak berpengaruh terhadap tinggi 
bibit padi Pandanwangi) ditolak dan H1 (lama perendaman benih padi Pandawangi dengan MOL (Mikroorganisme lokal) dari akar putri malu berpengaruh terhadap tinggi bibit padi Pandanwangi) diterima.

Hasil dari pengamatan respon tinggi tanaman bibit padi Pandanwangi terhadap lama perendaman benih padi Pandawangi dengan MOL (Mikroorganisme lokal) dari akar putri malu selama 4 minggu, dengan interval pemberian perlakuan setiap minggu dapat dilihat pada tabel 3 .

Tabel 3. Tinggi tanaman bibit Padi Pandanwangi

\begin{tabular}{ccccc}
\hline \multirow{2}{*}{ Perlakuan } & \multicolumn{4}{c}{ Rata-rata Tinggi Tanaman Padi Pandanwangi $(\mathrm{Cm})$} \\
\cline { 2 - 5 } & $1 \mathrm{MST}$ & $2 \mathrm{MST}$ & $3 \mathrm{MST}$ & $4 \mathrm{MST}$ \\
\hline A1 & $8.88 \mathrm{~cd}$ & $28.66 \mathrm{ab}$ & $32.78 \mathrm{a}$ & $35.10 \mathrm{~b}$ \\
A2 & $9.78 \mathrm{abc}$ & $28.38 \mathrm{ab}$ & $32.05 \mathrm{a}$ & $36.17 \mathrm{ab}$ \\
A3 & $10.66 \mathrm{a}$ & $28.61 \mathrm{ab}$ & $31.98 \mathrm{a}$ & $37.54 \mathrm{a}$ \\
A4 & $10.10 \mathrm{abc}$ & $27.35 \mathrm{ab}$ & $31.56 \mathrm{a}$ & $33.92 \mathrm{~b}$ \\
A5 & $9.09 \mathrm{bcd}$ & $27.22 \mathrm{~b}$ & $32.58 \mathrm{a}$ & $34.30 \mathrm{~b}$ \\
A6 & $10.22 \mathrm{ab}$ & $29.14 \mathrm{a}$ & $33.00 \mathrm{a}$ & $35.90 \mathrm{ab}$ \\
A7 & $9.29 \mathrm{bc}$ & $27.40 \mathrm{ab}$ & $32.57 \mathrm{a}$ & $34.06 \mathrm{~b}$ \\
A8 & $8.01 \mathrm{~d}$ & $23.09 \mathrm{c}$ & $24.23 \mathrm{~b}$ & $25.31 \mathrm{c}$ \\
\hline
\end{tabular}

Sumber : Data Primer (olahan) tahun 2018

Keterangan: Angka yang diikuti dengan huruf yang sama pada kolom yang sama tidak berbeda nyata pada taraf kepercayaan 5\% dengan Uji Tukey.

- Perlakuan: A1 = A1 = Perendaman benih dengan MOL (Mikroorganisme lokal)dari akar putri malu dengan lama waktu perendaman 4 jam, A2 = Perendaman benih dengan MOL dari akar putri malu dengan lama waktu perendaman $8 \mathrm{jam}, \mathrm{A} 3=$ Perendaman benih dengan MOL akar putri malu dengan lama waktu perendaman $12 \mathrm{jam}, \mathrm{A} 4=$ Perendaman benih dengan MOL dari akar putri malu dengan lama waktu perendaman $16 \mathrm{jam}, \mathrm{A} 5=$ Perendaman benih dengan MOL dari aknar putri malu dengan lama waktu perendaman $20 \mathrm{jam}, \mathrm{A} 6=$ Perendaman benih dengan MOL dari akar putri malu dengan lama waktu perendaman 24 jam, A7 = Perendaman benih dengan MOL dari akar putri malu dengan lama waktu perendaman 28 jam, A8 =Tanpa MOL (kontrol).

Dari hasil penelitian yang disajikan pada Tabel 3 menunjukkan bahwa perendaman benih dengan MOL (Mikroorganisme lokal) dari akar putri dapat berpengaruh terhadap tinggi bibit padi Pandanwangi. Pada pengamatan minggu ke-4 perlakuan A3 (lama perendaman benih dengan MOL (Mikroorganisme lokal)akar putri malu 12 jam ) merupakan perlakuan yang memberikan hasil rata-rata tinggi tanaman bibit padi Pandanwangi paling tinggi. Pengaruh langsung MOL (Mikroorganisme lokal) ini didasarkan atas kemampuan menyediakan dan memobilisasi atau menfasilitasi penyerapan berbagai unsur hara dalam tanah serta mensintesis atau memfalisitasi dan mengubah konsentrasi berbagai fitohormon pemacu tumbuh (Husen et al.,
2006 dalam Diana 2016). MOL yang mengandung unsur hara mikro dan makro dan juga mengandung bakteri yang berpotensi sebagai perombak bahan organik, perangsang pertumbuhan, dan sebagai agens pengendali hama dan penyakit tanaman, sehingga MOL dapat

digunakan baik sebagai pendekomposer, pupuk hayati, dan sebagai pestisida organik terutama sebagai fungisida (Purwasasmita, 2009). MOL ini dapat dibuat dengan memanfaatkan bahanbahan yang ada di sekitar, seperti buahbuahan busuk, limbah sayuran, keong mas dan lain-lain.

Tanaman putri malu tumbuh liar di pinggir jalan, lapangan terlantar, dan tempat - tempat terbuka yang terkena sinar matahari. Mikroba yang ada 
di daerah perakaran putri malu yakni: Rhizobium (Harahap, 2008).

Perlakuan perendaman secara langsung merupakan teknik invigorasi benih melalui imbibisi air secara terkontrol. Saat ini invigorasi merupakan salah satu alternatif yang dapat digunakan untuk mengatasi mutu benih kualitas rendah dengan cara memperlakukan benih sebelum ditanam dengan mengaktifkan kembali metabolisme benih sehingga benih siap memasuki fase perkecambahan. Selain proses invigorasi, proses perendaman mengakibatkan keserempakan perkecambahan serta mengurangi tekanan lingkungan. Keserempakan munculnya radikula akan berpengaruh terhadap keseragaman panjang hipokotil, parameter ini selanjutnya akan menunjukkan keragaman bibit dalam kemampuan mengangkat kotiledon (Heydecker, 1973 dalam Sulistyani 2014). Perendaman benih sebelum dikecambahkan dimaksudkan untuk mengaktifkan proses fisiologi yang berlangsung pada benih (Darmawan, 2008).

Menurut pendapat Santoso, dkk (2014) menyatakan bahwa perendaman benih dengan ZPT merupakan salah satu metode invigorasi untuk mempercepat tumbuhnya kecambah dan menghasilkan bibit yang vigor. Fahmi (2012) menambahkan pemberian ZPT pada lama perendaman yang tepat cenderung meningkatkan pertumbuhan tinggi kecambah dan tinggi bibit tanaman. Hal ini disebabkan karena tersediannya nutrisi yang cukup untuk pertumbuhan tanaman. Sesuai dengan pernyataan Dwijoseputro (2004) yang menyatakan bahwa pemberian ZPT pada benih tanaman dapat mendorong pemanjangan batang, sehingga menghasilkan kecambah dengan ukuran batang yang relatif lebih besar dan panjang hal ini dikarenakan kandungan dalam ZPT tersebut yang memiliki peran dalam proses biokimia pada benih.

Aplikasi Lama Perendaman Benih dengan Mol (Mikroorganisme Lokal) dari Akar Putri Malu dalam Memacu Pertumbuhan Bibit Padi Pandanwangi

[DOCUMENT TITLE]
Perlakuan lama perendaman benih dengan MOL akar putri malu menunjukkan rata-rata tinggi bibit padi Pandanwangi yang berbeda-beda mulai dari A1 sampai dengan A7 yang diberikan perlakuan perendaman benih dengan MOL akar putri malu. Hal ini diduga karena adanya pengaruh lama perendaman benih dengan MOL akar putri malu dengan interval waktu yang berbeda-beda. Hal ini sesuai dengan dengan pernyataan Darmawan, (2008) bahwa Perendaman benih sebelum dikecambahkan dimaksudkan untuk mengaktifkan proses fisiologi yang berlangsung pada benih. Interval perendaman biji juga ditunjukkan untuk melihat pengaruh fisiologis benih. Pemberian air melalui perendaman merupakan salah satu upaya yang dapat dilakukan untuk mempercepat munculnya kecambah, namun perendaman yang berlebihan akan berpengaruh kurang baik yakni dapat menyebabkan biji rusak dan busuk (Angadi \& Entz, 2002; Bachmann et al., 2002; Oberbauer et al., 2005).

\section{Jumlah Daun}

Parameter pertumbuhan padi Pandanwangi yang selanjutnya diukur adalah jumlah daun pada setiap unit penelitian bibit padi Pandanwangi pada 30 hst. Dari hasil ANOVA pengujian perlakuan lama perendaman benih padi Pandanwangi dengan MOL (Mikroorganisme Lokal) akar putri malu terhadap jumlah daun bibit padi Pandanwangi, menunjukkan ada pengaruh pada jumlah daun bibit padi Pandanwangi pada taraf $\alpha \quad 5 \%$ dengan nilai $\mathrm{P}$ value lebih kecil dari 0.05. Dengan demikian hipotesa H1 (lama perendaman benih padi Pandawangi dengan tanah serta mensintesis dan mengubah konsentrasi berbagai fitohormon pemicu pertumbuhan jumlah daun. dari akar putri malu berpengaruh terhadap jumlah daun bibit padi Pandanwangi) diterima.

Hasil pengamatan terhadap ratarata respon pengujian perlakuan lama 
perendaman benih padi pandanwangi dengan MOL (Mikroorganisme lokal) akar putri malu terhadap jumlah daun bibit padi Pandanwangi (Tabel 4.) menunjukkan perlakuan A4 (perendaman benih dengan (Mikroorganisme lokal)dari akar putri malu dengan lama waktu perendaman 16 jam) 3.63 helai yang menunjukkan rata-rata jumlah daun yang paling tinggi, nilai ini tidak berbeda nyata dengan perlakuan A3 (perendaman benih dengan (Mikroorganisme lokal) dari akar putri malu dengan lama waktu perendaman 12 jam) 3.23 helai, A5 (perendaman benih dengan (Mikroorganisme lokal) dari akar putri malu dengan lama waktu perendaman 20 jam) 3.33 helai, A6 (perendaman benih dengan (Mikroorganisme lokal)dari akar putri malu dengan lama waktu perendaman 24 jam) 3.50 helai, dan A7 (perendaman benih dengan (Mikroorganisme lokal) dari akar putri malu dengan lama waktu perendaman 28 jam) 3.56 helai. Akan tetapi berbeda nyata dengan perlakuan A1 (perendaman benih dengan (Mikroorganisme lokal) dari akar putri malu dengan lama waktu perendaman 4 jam) 3.13 helai, A2 (perendaman benih dengan (Mikroorganisme lokal) dari akar putri malu dengan lama waktu perendaman 8 jam) 3.03 helai, dan A8 (kontrol tanpa (Mikroorganisme lokal)) 2.60 helai.

Perlakuan A4 (lama perendaman benih dengan MOL (Mikroorganisme lokal) dari akar putri malu selama 16 jam ) merupakan perlakuan yang memberikan hasil yang paling tinggi pada jumlah daun bibit padi Pandanwangi. Hal ini diduga karena adanya berbagai jenis bakteri menguntungkan yang ada dalam MOL (Mikroorganisme lokal). Pengaruh langsung MOL (Mikroorganisme lokal) ini didasarkan atas kemampuan menyediakan dan memobilitasi atau menfasilitasi penyerapan berbagai unsur hara dalam tanah serta mensintesis dan mengubah konsentrasi berbagai fitohormon pemicu pertumbuhan jumlah daun.

Tabel 4 Rata-rata jumlah daun bibit padi Pandanwangi pada setiap perlakuan

\begin{tabular}{lc}
\hline \multicolumn{1}{c}{ Perlakuan } & $\begin{array}{c}\text { Rata-rata jumlah daun } \\
\text { (helai) }\end{array}$ \\
\hline A1 = lama perendaman benih dengan MOL akar putri malu 4 jam & $3.13 \mathrm{bc}$ \\
A2 $=$ lama perendaman benih dengan MOL akar putri malu 8 jam & $3.03 \mathrm{c}$ \\
A3 $=$ lama perendaman benih dengan MOL akar putri malu 12 jam & $3.23 \mathrm{abc}$ \\
A4 $=$ lama perendaman benih dengan MOL akar putri malu 16 jam & $3.63 \mathrm{a}$ \\
A5 $=$ lama perendaman benih dengan MOL akar putri malu 20 jam & $3.33 \mathrm{abc}$ \\
A6 $=$ lama perendaman benih dengan MOL akar putri malu 24 jam & $3.50 \mathrm{ab}$ \\
A7 $=$ lama perendaman benih dengan MOL akar putri malu 28 jam & $3.56 \mathrm{a}$ \\
A8 $=$ Kontrol & $2.60 \mathrm{~d}$
\end{tabular}

Sumber : Data Primer (olahan) tahun 2018

Keterangan: Angka yang diikuti dengan huruf yang sama pada kolom yang sama tidak berbeda nyata pada taraf kepercayaan 5\% dengan Uji Tukey.

Diduga pula tersedianya unsur hara makro dan mikro yang terdapat di dalam tanah serta mensintesis dan mengubah konsentrasi berbagai fitohormon pemicu pertumbuhan jumlah daun. Akar putri malu serta unsur $\mathrm{N}$ yang didapati dari hasil fiksasi dari udara oleh Azotobacter sp . Hal ini sesuai dengan pernyataan yang dikemukakan Thompson dan Kelly (1997) dalam Diana (2016) bahwa nitrogen dapat mempercepat pertumbuhan dan memberikan hasil yang lebih besar mendorong pertumbuhan vegetasi seperti daun, batang dan akar yang mempunyai peranan penting di dalam tanaman. Selain dari itu, peranan unsur $\mathrm{N}$ bagi tanaman yaitu meningkatkan pertumbuhan 
tanaman menjadi hijau karena mengandung klorofil yang berperan dalam fotosintesis. Unsur tersebut juga bermanfaat untuk mempercepat pertumbuhan tinggi tanaman, memperbanyak jumlah anakan, mempengaruhi lebar dan panjang daun, membuat buah menjadi besar, menambahkan kadar protein dan lemak bagi tanaman (Pitojo, 1997 dalam Diana, 2016)

Perlakuan perendaman secara langsung merupakan teknik invigorasi benih melalui imbibisi air secara terkontrol. Saat ini invigorasi merupakan salah satu alternatif yang dapat digunakan untuk mengatasi mutu benih kualitas rendah dengan cara memperlakukan benih sebelum ditanam dengan mengaktifkan kembali metabolisme benih sehingga benih siap memasuki fase perkecambahan. Selain proses invigorasi, proses perendaman mengakibatkan keserempakan perkecambahan serta mengurangi tekanan lingkungan. Keserempakan munculnya radikula akan berpengaruh terhadap keseragaman panjang hipokotil, parameter ini selanjutnya akan menunjukkan keragaman bibit dalam kemampuan mengangkat kotiledon (Heydecker, 1973) Perendaman benih sebelum dikecambahkan dimaksudkan untuk mengaktifkan proses fisiologi yang berlangsung pada benih (Darmawan, 2008).

$$
\text { Suyatmi, }
$$$$
\mathrm{dkk}
$$

menambahkan, perendaman benih dengan hormon pada waktu tertentu dapat menyebabkan meningkatnya proses masuknya air kedalam kulit benih, sehingga menyebabkan daya kecambah benih menjadi meningkat. Fitohormon adalah hormon tumbuhan berupa senyawa organik yang dibuat pada suatu bagian tanaman dan kemudian diangkut ke bagian lain dengan konsentrasi rendah menyebabkan suatu dampak fisiologi, peran suatu hormon adalah merangsang pertumbuhan, pembelahan sel, pemanjangan sel dan ada yang menghambat pertumbuhan (Syamsuri, dalam Tubagus 2014).

Perlakuan lama perendaman benih dengan MOL (Mikroorganisme lokal) akar putri malu menunjukkan rata-rata jumlah daun bibit padi Pandanwangi yang beda-beda mulai dari A1 sampai dengan A7 yang diberikan perlakuan perendaman benih dengan MOL (Mikroorganisme lokal) akar putri malu. Hal ini diduga karena adanya pengaruh lama perendaman benih dengan MOL (Mikroorganisme lokal) akar putri malu dengan interval waktu yang berbeda-beda. Hal ini sesuai dengan pernyataan Darmawan, (2008) bahwa Perendaman benih sebelum dikecambahkan dimaksudkan untuk mengaktifkan proses fisiologi yang berlangsung pada benih. Interval perendaman biji juga ditunjukkan untuk melihat pengaruh fisiologis benih. Pemberian air melalui perendaman merupakan salah satu upaya yang dapat dilakukan untuk mempercepat munculnya kecambah, namun perendaman yang berlebihan akan berpengaruh kurang baik yakni dapat menyebabkan biji rusak dan busuk (Angadi \& Entz, 2002; Bachmann et al., 2002; Oberbauer et al., 2005).

\section{Panjang Akar}

Parameter pertumbuhan bibit padi Pandanwangi yang selanjutnya diukur adalah panjang akar pada 30 hst. Dari hasil ANOVA pengujian perlakuan lama perendaman benih padi Pandanwangi dengan MOL (Mikroorganisme lokal) akar putri malu terhadap panjang akar bibit padi Pandanwangi, menunjukkan ada pengaruh pada panjang akar bibit padi Pandanwangi pada taraf $\alpha \quad 5 \%$ dengan nilai $\mathrm{P}$ value lebih kecil dari 0.05. Dengan demikian hipotesa H1 (lama perendaman benih padi Pandawangi dengan MOL (Mikroorganisme lokal) dari akar putri malu berpengaruh terhadap panjang akar bibit padi Pandanwangi) diterima. 
Berikut ini adalah rata-rata dari respon pengujian perlakuan lama perendaman benih padi Pandanwangi dengan MOL (Mikroorganisme lokal) dari akar putri malu terhadap panjang akar bibit padi Pandanwangi.

Hasil pengamatan terhadap ratarata respon pengujian perlakuan lama perendaman benih padi pandanwangi dengan MOL (Mikroorganisme lokal) akar putri malu terhadap panjang akar padi Pandanwangi menunjukkan perlakuan A4 (perendaman benih dengan MOL (Mikroorganisme lokal) dari akar putri malu dengan lama waktu perendaman 16 jam) $30.10 \mathrm{~cm}$ yang menunjukkan ratarata panjang akar yang paling tinggi, yang tidak berbeda nyata dengan perlakuan A3 (perendaman benih dengan MOL (Mikroorganisme lokal) dari akar putri malu dengan lama waktu perendaman 12 jam) $29.25 \mathrm{~cm}$, dan A6 (perendaman benih dengan MOL (Mikroorganisme lokal) dari akar putri malu dengan lama waktu perendaman 24 jam) $25.89 \mathrm{~cm}$. Akan tetapi berbeda nyata dengan perlakuan A1 (perendaman benih dengan MOL (Mikroorganisme lokal) dari akar putri malu dengan lama waktu perendaman 4 jam) $21.10 \mathrm{~cm}, \mathrm{~A} 2$ (perendaman benih dengan MOL (Mikroorganisme lokal) dari akar putri malu dengan lama waktu perendaman 8 jam) $20.11 \mathrm{~cm}$, A5 (perendaman benih dengan MOL (Mikroorganisme lokal) dari akar putri malu dengan lama waktu perendaman 20 jam) $20.50 \mathrm{~cm}, \mathrm{~A} 7$ (perendaman benih dengan MOL (Mikroorganisme lokal) dari akar putri malu dengan lama waktu perendaman 28 jam) $24.07 \mathrm{~cm}$, dan perlakuan A8 (kontrol tanpa MOL (Mikroorganisme lokal)) $15.53 \mathrm{~cm}$.

Tabel 5. Rata-rata panjang akar bibit padi Pandanwangi pada setiap perlakuan.

\begin{tabular}{cc}
\hline \multicolumn{1}{c}{ Perlakuan } & $\begin{array}{c}\text { Rata-rata panjang akar } \\
(\mathrm{cm})\end{array}$ \\
\hline A1 = lama perendaman benih dengan MOL akar putri malu 4 jam & $21.10 \mathrm{c}$ \\
A2 = lama perendaman benih dengan MOL akar putri malu 8 jam & $20.11 \mathrm{~cd}$ \\
bA3 = lama perendaman benih dengan MOL akar putri malu $12 \mathrm{jam}$ & $29.25 \mathrm{a}$ \\
A4 = lama perendaman benih dengan MOL akar putri malu 16 jam & $30.10 \mathrm{a}$ \\
A5 = lama perendaman benih dengan MOL akar putri malu 20 jam & $20.50 \mathrm{c}$ \\
A6 = lama perendaman benih dengan MOL akar putri malu 24 jam & $25.89 \mathrm{ab}$ \\
A7 = lama perendaman benih dengan MOL akar putri malu 28 jam & $24.07 \mathrm{bc}$ \\
A8 = Kontrol & $15.53 \mathrm{~d}$ \\
\hline
\end{tabular}

Sumber : Data Primer (olahan) tahun 2018

Keterangan: Angka yang diikuti dengan huruf yang sama pada kolom yang sama tidak berbeda nyata pada taraf kepercayaan 5\% dengan Uji Tukey

Perlakuan lama perendaman benih dengan MOL (Mikroorganisme lokal) akar putri malu menunjukkan rata-rata panjang akar bibit padi Pandanwangi yang beda-beda mulai dari A1 sampai dengan A7 yang diberikan perlakuan perendaman benih dengan MOL (Mikroorganisme lokal) akar putri malu. Hal ini diduga karena adanya pengaruh lama perendaman benih dengan MOL (Mikroorganisme lokal)akar putri malu dengan interval

Aplikasi Lama Perendaman Benih dengan Mol (Mikroorganisme Lokal) dari Akar Putri Malu dalam Memacu Pertumbuhan Bibit Padi Pandanwangi

[DOCUMENT TITLE] waktu yang berbeda-beda.. Suyatmi, dkk (2006) yang menyatakan bahwa perendaman benih dengan hormon pada waktu tertentu dapat menyebabkan meningkatnya proses masuknya air kedalam kulit benih, sehingga menyebabkan daya kecambah benih menjadi meningkat. Kemudian ditambahkan oleh Darmawan, (2008) bahwa Perendaman benih sebelum dikecambahkan dimaksudkan untuk 
mengaktifkan proses fisiologi yang berlangsung pada benih. Interval perendaman biji juga ditunjukkan untuk melihat pengaruh fisiologis benih. Pemberian air melalui perendaman merupakan salah satu upaya yang dapat dilakukan untuk mempercepat munculnya kecambah, namun perendaman yang berlebihan akan berpengaruh kurang baik yakni dapat menyebabkan biji rusak dan busuk (Angadi \& Entz, 2002; Bachmann et al., 2002; Oberbauer et al., 2005). Dwijasputro (2004), menyatakan bahwa panjang pendeknya perakaran ditentukan oleh faktor luar tumbuh, seperti jenis tanah, kadar air, dan kandungan nutrisi dalam media tumbuh.

\section{Bobot Segar}

Parameter pertumbuhan bibit padi Pandanwangi yang selanjutnya adalah bobot segar bibit yang diukur dengan menimbang bibit segar padi Pandanwangi. Dari hasil ANOVA pengujian perlakuan lama perendaman benih padi Pandanwangi dengan MOL (Mikroorganisme lokal) akar putri malu terhadap bobot segar bibit padi Pandanwangi, menunjukkan ada pengaruh pada bobot segar bibit padi Pandanwangi pada taraf $\alpha 5 \%$ dengan nilai $\mathrm{P}$ value lebih kecil dari 0.05. Dengan demikian hipotesa H1 (lama perendaman benih padi Pandawangi dengan MOL (Mikroorganisme lokal) dari akar putri malu berpengaruh terhadap bobot segar bibit padi Pandanwangi) diterima

Hasil pengamatan terhadap ratarata respon pengujian perlakuan lama perendaman benih padi pandanwangi dengan MOL (Mikroorganisme lokal)akar putri malu terhadap bobot segar bibit padi Pandanwangi (Tabel 6) menunjukkan perlakuan A4 (perendaman benih dengan
MOL (Mikroorganisme lokal)dari akar putri malu dengan lama waktu perendaman 16 jam) 0.30 gram yang menunjukkan rata-rata bobot segar yang paling tinggi, tetapi tidak berbeda nyata dengan A1 (perendaman benih dengan MOL (Mikroorganisme lokal)dari akar putri malu dengan lama waktu perendaman 4 jam) 0.28 gram, A2 (perendaman benih dengan MOL (Mikroorganisme lokal) dari akar putri malu dengan lama waktu perendaman 8 jam) 0.27 gram, A3 (perendaman benih dengan MOL (Mikroorganisme lokal)dari akar putri malu dengan lama waktu perendaman 12 jam) 0.29 gram, A5 (perendaman benih dengan MOL dari akar putri malu dengan lama waktu perendaman 20 jam) 0.28 gram, A6 (perendaman benih dengan MOL dari akar putri malu dengan lama waktu perendaman 24 jam) 0.27 gram, dan A7 (perendaman benih dengan MOL dari akar putri malu dengan lama waktu perendaman 28 jam) 0. 29 gram.

Ketujuh perlakuan perendaman benih dengan MOL menunjukkan hasil rata-rata bobot segar bibit yang berbeda nyata dengan perlakuan Kontrol A8 (tanpa MOL (Mikroorganisme lokal)) 0.20 gram. Hasil dari perlakuan A8 (tanpa perendaman dengan) merupakan perlakuan yang paling terendah dengan rata-rata bobot segar 0.20 gram. Kondisi ini dikarenakan tidak tersedianya unsur hara salah satunya unsur hara N, P dan K yang cukup yang dapat diserap oleh tanaman sehingga cenderung terhambat. Suatu tanaman apabila kekurangan unsur hara akan mengalami gangguan pertumbuhan.

Tabel 6. Rata-rata bobot segar bibit padi Pandanwangi pada setiap perlakuan.

\begin{tabular}{cc}
\hline Perlakuan & $\begin{array}{c}\text { Rata-rata bobot segar } \\
\text { (gram) }\end{array}$ \\
\hline A1 = lama perendaman benih dengan MOL akar putri malu 4 jam & $0.28 \mathrm{a}$
\end{tabular}




$\begin{array}{rlr}\text { A2 } & =\text { lama perendaman benih dengan MOL akar putri malu } 8 \text { jam } & 0.27 \mathrm{a} \\ \text { A3 } & =\text { lama perendaman benih dengan MOL akar putri malu } 12 \text { jam } & 0.29 \mathrm{a} \\ \text { A4 } & =\text { lama perendaman benih dengan MOL akar putri malu } 16 \text { jam } & 0.30 \mathrm{a} \\ \text { A5 } & =\text { lama perendaman benih dengan MOL akar putri malu } 20 \text { jam } & 0.28 \mathrm{a} \\ \text { A6 } & =\text { lama perendaman benih dengan MOL akar putri malu } 24 \text { jam } & 0.27 \mathrm{a} \\ \text { A7 } & =\text { lama perendaman benih dengan MOL akar putri malu 28 jam } & 0.29 \mathrm{a} \\ \text { A8 } & =\text { Kontrol } & 0.20 \mathrm{~b}\end{array}$

Sumber : Data Primer (olahan) tahun 2018

Keterangan: Angka yang diikuti dengan huruf yang sama pada kolom yang sama tidak berbeda nyata pada taraf kepercayaan 5\% dengan Uji Tukey.

Seperti yang dikemukakan Manschner (1986) dalam Wijayanti dan Diana (20016) bahwa tanaman yang kahat hara $\mathrm{N}$ (nitrogen) mengakibatkan pertumbuhan lambat, daun pucat dan tidak hijau berseri warnanya. Tanaman yang kahat hara P (fosfor), warna daun berubah lebih tua tetapi tidak merata sedang akar tumbuh tidak sempurna dan apabila kahat unsur hara K (kalium) daun paling bawah berubah warna menjadi coklat dengan bercak-bercak gelap, dalam keadaan parah daun menjadi keriting (Wijayanti, dkk, 1998 dalam Diana, 2016).

Interval perendaman biji juga ditunjukkan untuk melihat pengaruh fisiologis benih. Pemberian air melalui perendaman merupakan salah satu upaya yang dapat dilakukan untuk mempercepat munculnya kecambah, namun perendaman yang berlebihan akan berpengaruh kurang baik yakni dapat menyebabkan biji rusak dan busuk (Angadi \& Entz, 2002; Bachmann et al., 2002; Oberbauer et al., 2005 dalam Sulistyani dkk, 2014).

\section{KESIMPULAN DAN SARAN}

\section{Kesimpulan}

Lama perendaman benih dengan MOL (Mikroorganisme lokal)dari akar putri malu berpengaruh terhadap pertumbuhan bibit tanaman padi
Pandanwangi. Hasil penelitian menunjukkan bahwa secara umum perlakuan perendaman benih dengan MOL (Mikroorganisme lokal) berpengaruh signifikan dibandingkan dengan benih yang direndam tanpa MOL (Mikroorganisme lokal). Perlakuan A4 (lama perendaman benih dengan MOL (Mikroorganisme lokal) selama 16 jam) menunjukkan perlakuan yang memberikan nilai paling baik di setiap parameter, yaitu terhadap parameter persenatse perkecambahan benih $(98,66 \%)$, persentase bibit tumbuh normal (86\%), rata-rata tinggi tanaman $37.54 \mathrm{~cm}$, ratarata jumlah daun (3.63 helai), rata-rata panjang akar $(30,10 \mathrm{~cm})$, rata-rata bobot segar bibit padi pandanwangi (0.30 gram)

\section{Saran}

1. Perlunya adanya penelitian lanjutan mengenai lama perendaman benih dengan MOL (Mikroorganisme lokal) akar putri malu pada tanaman padi Pandanwangi yang tidak hanya pada fase vegetatif awal tetapi sampai fase generatif.

2. Untuk pengujian perkecambahan benih padi Pandanwangi lama perendaman benih dengan MOL (Mikroorganisme lokal) akar putri malu dengan lama waktu perendaman 4-16 jam saja sudah cukup. 


\section{DAFTAR PUSTAKA}

Andoko, A. 2002. Budidaya padi secara organik. Penebar Swadaya, Jakarta. 96 hal.

Azhar, C. 2010. Kajian morfologi dan produksi tanaman padi (Oryza sativa L.) Varietas cibogo hasil radiasi sinar gamma Pada generasi $\mathrm{M}_{3}$. Fakultas Pertanian, Medan.

Adnan, 2017. Pengarub Konsentrasi dan Lamanya Perendaman Dalam Larutan Giberelin Terbadap Perkecambahan Benih Kakao. Jurnal. Universitas Samudra.

Angadi, S.V. \& M.H. Entz (2002). Water relationsof standar height and dwarf sunflower cultivars. Crop Science, 42, 152-159.

Ambarwati, 2007. Studi Actinomycetes yang Berpotensi Menghasilkan Antibiotik. Dari Rhizosfer Tumbuban Putri Malu (mimosa pudica, Linn) dan Kucingkucingan (Acalypha Indica L.). jurnal Penelitian Sains dan Teknologi. Universitas Muhammadiyah Sukarata.

Ashari, 1995. Holtikultura Aspek Budidaya. Universitas Indonesia. Jakarta.

Bachmann, J.; S.A. Grant \& P.R. van der Ploeg (2002). Temperature dependence of water retention curves for wettable and water reppellent soils. Soil Science Society of America Journal, 66, 44-52.

Darmawan (2008). Pertumbuban dan laju fotosintesis bibit tanaman jarak pada tingkat perendaman air dan pemupukan nitrogen berbeda. Jurnal Agrivigor, 7, 293-299.

Dewi, A.I.R 2008. Peranan dan Fungsi Fitohormon Bagi Pertumbuhan Tanaman. Bandung. Universitas Padjadjaran.

Kartika, B.A. 2011. Teknik Ekplorasi dan Pengembangan Bakteri Pseudemonas Flourescens. Laboratorium PHP Bayumas.

Aplikasi Lama Perendaman Benih dengan Mol (Mikroorganisme Lokal) dari Akar Putri Malu dalam Memacu Pertumbuhan Bibit Padi Pandanwangi

[DOCUMENT TITLE]
Dinas Pertanian Kabupaten Cianjur. 2011. Komoditas Unggulan Kabupaten Cianjur. Dinas Pertanian Kabupaten Cianjur, Cianjur.

Diana Rahayu. 2016. Respon Pertumbuhan Tanaman Cabai (Capsicum annum L.) Terhadap Pemberian Giberelin dan RPTT (Rizobakteri Pemacu Tumbuh Tanaman) Akar Putri Malu. Skripsi. Universitas Suryakancana. Cianjur.

Dwijoesoputro, 2004. Fisiologis Tumbuhan. Gadjah Mada Press, Yogyakarta

Goldsworthy, P.R. dan Fither, N.M. 1992. Fisiologi Tanaman Budidaya Tropik (Diterjemahkan oleh: Tohari). Universitas Gadjah Mada Press. Yogyakarta.

Haq. A.S. 2009. Pengarub ekstrak herba putri malu (mimosa pudica, Linn) Terhadap efek solusi pada mencit bal $b / c$. Skripsi. Unversitas Diponegoro. Semarang.

Harahap, I.P. 2008. Studi Pertumbuhan Isolasi Bakteri Rhizobium Dari Bintil Akar Tanaman Putri Malu (mimosa pudica, L) Serta Pemnfaatannya Sebagi Pupuk Hayati (Biofertilizer) Dengan Menggunakan Bentonit sebagai medium pembawa. Skripsi. Universitas Sumatera Utara. Medan.

Husen . et,al. 2006.Rizobakteri Pemacu Tumbuh Tanaman. Buku Pupuk Organik dan Pupuk Hayati. Balai Penelitian dan Pengembangan Sumberdaya Lahan Pertanian. 191-209.

Jaya, A.M. 2010. Isolasi dan Uji Efektivitas Antibakteri Senayawa Saponin Dari Akar Putri Malu (mimisa Pudica). Universitas Islam Negeri Maulana Malik Ibrahim. Malang.

Kelly, T. 2005. Pemanfaatan Bakteri Perakaran Pemicu Pertumbuban Tanaman (Plant Growht Promoting Rhizobakter) untuk Mengendalikan Penyakit Mosaik Tembakau (Tobacco 
Mosaik Virus) pada Tanaman Cabai. Skripsi Institut Pertanian Bogor.

Koryati, T. 2004. 'Pengaruh Penggunaan Mulsa dan Pemupukan Urine Kelinci".

http://www.kusnendar.web.id/2 013/pupuk-organik-dari-kotorandan-urine-kelinci-html. Diakses tanggal 24 Novemberi 2017.

Kuswanto, H. 1996. Dasar-dasar Teknologi Produksi dan Sertifikasi Benih. Edisi ke-1. Andi. Yogyakarta. Heydecker, W. (1973). Germination of an Idea: The Priming of Seeds. School of Agriculture Research, University of Nottingham, Nottingham.

Makarim, A.K., dan Suhartatik, E. 2009. Morfologi dan fisiologi tanaman padi. Balai Besar Penelitian Tanaman Padi. http://www.litbang.pertanian.go.i $\mathrm{d} /$ special/padi/bbpadi 2009 itk p_11.pdf. Diakses tanggal 10 juni 2015.

Masyarakat Pelestari Padi Pandanwangi Cianjur. 2015. Buku Permohonan Pendaftaran Indikasi Geografis Beras Pandanwangi Cianjur. MP3C; Cianjur

Menteri Pertanian Republik Indonesia Nomor

163/kpts/LB.2040/3/2004

tentang Pelepasan Galur Padi

Sawah Lokal Pandanwangi Cianjur Sebagai Varietas Unggul dengan Nama Pandanwangi.

Muhammad, Acep. 2015. Kelimpahan Hama dan Musuh Alami pada Pertanaman Padi Varietas Pandanwangi di Kecamatan Warungkondang Kabupaten Cianjur. Departemen Proteksi Tanaman Fakultas Pertanian Institut Pertanian Bogor; Bogor

Narasi, C. 2010. Peran Mikroba Dalam Pertanian Organik. Fakultas Pertanian Universitas Padjadjaran. Bandung.

Aplikasi Lama Perendaman Benih dengan Mol (Mikroorganisme Lokal) dari Akar Putri Malu dalam Memacu Pertumbuhan Bibit Padi Pandanwangi

[DOCUMENT TITLE]
Oberbauer, S.F.; B.R. Starin \& N. Fletcher (2005). Effects of CO enrichment on seedling physiology and growth of two tropical tree species. Physiologia Plantarum, 65, 352356.

Pitojo, S. 2005. Benih Kacang Tanah. Yogyakarta: Kanisius.

Prima ghandi. 2008. Analisis Usaha dan Tataniaga Padi Varietas Unggul (Studi Kasus Padi Pandanwangi di Kecamatan Warungkondang Kabupaten Cianjur). Skripsi. Institut Pertanian Bogor.

Purwasasmita, M. 2009. Mikeroorganisme Lokal Sebagai Pemicu Siklus Kehidupan dalam Bioreaktor Tanaman. Seminar Nasional Teknik Kimia Indonesia. 19 - 20 Oktober 2009.

Rahmawati, 2017. Pengujian perlakuan Trichoderma spp pada media tanam terhadap vigor benih dan pertumbuban bibit pandanwangi cianjur. Skripsi. Universitas Suryakancana Cianjur

Ratnasari Tuti, 2010. Kajian Pembelahan Umbi Benih dan Perendaman dalam Giberelin pada Pertumbuban dan Hasil Tanaman Kentang (Solanumtuberosum L.). Skripsi.Universitas Sebelas Maret,Surakarta.

Ramli, T.A. dan Yety S 2015. Penyuluhan Tentang Perlindungan Hukum Indikasi Geografis Beras Pandanwangi Cianjur jawa Barat sebagai Wujud Sumbangsih UNISBA dalam Meningkatkan Indeks Pembangunan Manusia (UPM). Dharmakarya: Jurnal Aplikasi Ipteks untuk Masyarakat, Mei 2015. 4(1): 27-36

Santoso Imam, Sulistyani, dan Sudarsianto, 2014. Studi Perkecambahan Benih Kakao Melalui Metode Perendaman. Pusat Penelitian Kopi dan Kakao Indonesia, Jember.

Satria, R.S. 2013. Respon Pertumbuban Dan Produksi Tanaman Caisin (brassica 
chinensis L.) terhadap waktu Aplikasi MOL (Mikroorganisme lokal) Dari Rebung Bambu( (Bambusa sp). Skripsi, Universitas Suryakancana Cianjur.

Sitompul dan Guritno, 1995. Analisi Pertumbuhan Tanaman. Gajah Mada University Press. Yogyakarta.

Silvia. 2014. Pengaruh konsentrasi Giberelin dan Lama Perendaman Terhadap Perkecambahan Biji Sirsak (Anonna muricata L.). Jurnal. Universitas Patimura. Ambon.

Sulistyani Pancaningtyas, Teguh Iman Santoso dan Sudarsianto. 2014. Studi Perkecambahan Benih Kakao MelaluiMetode Perendaman. Pelita Perkebunan, Volume 30, Number 3.

Sudirman dan Ade, I. 2003. Mina padi budida ikan bersama padi. Penebar Swadaya, Jakarta. 73 hal.

Suyatmi, Dwi Hastuti, Darmanti Sri. 2006. Pengaruh Lama Perendaman dan Konsentrasi Asam Sulfat (H2SO4) terhadap Perkecambahan Benih Jati Tumbuhan Jurusan Biologi F. MIPA UNDIP.

Suryana R.N, Dwi Rachmina, Sumedi dan Tanti N. 2009. Ajian Efisiensi Daya Saing Padi Pandawangi Indonesia. Ringkas Eksekutif Hasil-hasil Penelitian Tahun 2009 dalam kerjasama Kemintraan Penelitian Pertanian dengan Perguruan Tinggi. Institut Pertanian Bogor. Bogor.

Sutopo, L. 1988. Teknologi Beni ih. Jakarta: Raja Grafindo Persada.

Syahid, M.A.N. 2009. Pengarub ekstrak putri malu (mimosa pudica, Linn.) terhadap mortalitas escarin suum, goeze in vitro. Skripsi Universitas Sebelas Maret. Surakarta.

Wahyudi, 2010. Petunjuk Praktiks Bertanam Sayuran. PT. Agromedia Pustaka, Jakarta Selatan.

Winarno, 2001. Pengaruh Pemberian Hormon Giberelin Terhadap Perkecambahan Benib Tanaman. Balai Besar Perbenihan dan Proesi Tanaman Perkebunan. Surabaya.

Wijanyanti, A dan Indradewa, D. 2004. Deteksi Kahat Hara N, P, K, Mg dan Ca Pada Tanaman Bunga Matahari Dengan Sistem Hidroponik. Yogyakarta. Universitas Gadjah Mada.

Yasin, M.K. 2013. Uji berbagai isolate bakteri pemacu pertumbuhan tanaman (BPPT) terhadap pertumbuban tanaman cabai (Capsicum annum L.). Skripsi. Universitas Suryakancana Cianjur. 